\title{
Emerging Paradigms of Corporate Social Responsibility, Regulation, and Governance: Introduction to the Thematic Symposium
}

\author{
Bimal Arora ${ }^{1} \cdot$ Arno Kourula $^{2,3} \cdot$ Robert Phillips $^{4}$
}

Received: 4 April 2019 / Accepted: 10 June 2019 / Published online: 14 June 2019

(c) Springer Nature B.V. 2019

\section{Introduction to the Thematic Symposium}

Over the last decade, corporate social responsibility (CSR) has experienced a "governance turn" as scholars began examining the institutionally embedded nature of CSR (Brammer et al. 2012; Campbell 2007; Matten and Moon 2008; Waddock 2008). This was also a period when foundational work in institutional and political CSR appeared, including Habermasian approaches (Scherer and Palazzo, 2007), corporate citizenship (Matten and Crane 2005), and corporate accountability through multi-stakeholder initiatives (MSIs) (Gilbert and Rasche 2007). Simultaneously, scholars utilizing post-colonial insights began surfacing the negative effects of CSR (Banerjee 2008). In short, CSR has emerged as an important part of a wider field of institutions governing the corporation and the economy, perhaps even as a mode of governance in itself (Brammer et al. 2012, p. 3). The aim of this thematic symposium of the Journal of Business Ethics is to contribute to and further these debates and highlight some questions still remaining to be addressed.

The governance turn has led to substantial growth in research using institutional theory to examine CSR (Pisani et al. 2017). CSR as an institutionally embedded phenomenon is often understood as either a form of institutionally induced self-regulation by firms and/or industries, or private, voluntary regulation of supply chains in the transnational sphere by large multinational firms. Such private and voluntary regulation in the transnational sphere contributes to global governance processes, in response to a perceived

Robert Phillips

rp.richmond@gmail.com

1 Aston Business School, Aston University, Birmingham, UK

2 University of Amsterdam Business School, Amsterdam, The Netherlands

3 Aalto University School of Business, Espoo, Finland

4 Schulich School of Business, York University, Toronto, Canada absence of a global governing authority (Djelic and Etchanchu 2015; Fransen and Kolk 2007; Sheehy 2015).

Perhaps as a result of this growing research on corporations as citizens, political actors, and participants in multi-stakeholder initiatives, there is greater awareness of remaining and newer complexities and tensions evident in both business-driven and multi-stakeholder forms of governance (Levy 2008). Such governance initiatives are usually played out at the transnational level, where the form, meaning, intention, and implications of CSR remain highly contested (Brammer et al. 2012; Kourula et al. 2018). Even on their own terms as heuristics and frameworks, the notions of corporations as citizens and political actors as well as multistakeholder forms of governance by non-state actors remain plagued by a multitude of challenges (Arora 2017; Goodman and Arenas 2015; Hussain and Moriarty 2018; Sethi and Schepers 2014; Utting 2014; Whelan 2012). While the developing world, in some instances, may have experienced economic gains from the practices of outsourcing and offshoring by modern multinational firms, there has also been a simultaneous rise in global, regional, national, and local inequalities, destruction of the environment, a diminished biodiversity, and inappropriate application of technologies (Margolis and Walsh 2003; Wilks 2013). Multi-stakeholder forms of governance have not been able to solve these negative impacts. The viability of their aims, the lack of representation in their processes, and their questionable effectiveness remain debated. This thematic symposium addresses these challenges and debates and the four papers highlight and theorize some of these issues of the emerging paradigms of CSR, regulation and governance.

Alexander (2019) expands on lead firm governance in global value chains and global production networks. She examines sustainable practices in buyer-driven industries and across different stages of production, particularly related to lower-tier suppliers. She offers important insights about new governance approaches utilized by lead firms. Her research suggests that the lead firms work through vertical 
buyer-seller links and/or develop new horizontal relationships, which link lead firms with lower-tier suppliers and governance processes in suppliers' local productive systems. She proposes five types of governance mechanisms involving vertical and/or horizontal links.

Many studies across disciplines demonstrate challenges around labor issues in global supply chains. Lee et al. (2019) propose a collaborative governance framework, suggesting it as an alternative governance type. Such a collaborative governance involves a coalition among competing firms aimed at increasing the relational leverage over suppliers and/or host country specific labor issues. The authors examine the rationale behind such collaborative governance initiatives and discuss opportunities and challenges.

Graz et al. (2019) review the effectiveness of transnational private governance on labor standards and emphasize the role of labor agency. They argue that the relationship between transnational private regulatory initiatives and labor agency depends on three particular competences. They then develop a framework for a hybrid production regime to examine workers' capacity to act at the local level. This, they argue, depends on the institutionalization of capitallabor relations between the transnational and national levels.

Jackson et al. (2019) examine the effects of non-financial disclosure on CSR. They conceptualize trade-offs between two ideal types of regulation in relation to CSR. Their analysis of data from 24 OECD countries shows that, on the one hand, firms in countries that require non-financial disclosure adopt significantly more CSR activities. On the other hand, they find that the regulation on non-financial disclosure does not influence corporate irresponsibility of firms. They go on to discuss the limits of mandatory non-financial disclosure in addressing regulatory trade-offs between stringency and flexibility in the field of CSR.

\section{Remaining Challenges}

While research on the institutional governance of responsible business conduct is on the rise (Kourula et al. 2019; Pisani et al. 2017), questions remain. For example, what types of actors are-and should be-involved in organizing collaborative governance? How is transnational regulation understood and implemented nationally? How are understanding and implementation affected by local insights? The interactions, tensions, and contestations between local, national, and transnational levels of governance need further research and theorizing (Alamgir and Banerjee 2018; Ford and Gillan 2017; Goodman and Arenas 2015; Manning et al. 2012; Wijen 2014). Particular attention is needed to the largely missing voices of the governed or marginalized (Banerjee 2018; Draude 2017; Ozkazanc-Pan 2018) and inclusivity of stakeholders in developing and emerging economies, where CSR as a mode of transnational governance usually plays out (Arora et al. 2019; Utting and Marques 2009). Scholars also increasingly recognize and call for corporations to collaborate with government and various non-state actors in dealing with grand challenges (Ferraro et al. 2015; George 2016). In this issue, Alexander (2019) explores processes within global production networks; Lee et al. (2019) examine interactions between competing firms; Graz et al. (2019) emphasize the role of labor; and Jackson et al. (2019) highlight the importance and limits of national institutions and regulation.

Perhaps the most challenging task for scholars is understanding and evaluating outcomes of CSR as a mode of governance. Further research is needed to determine whether private and voluntary governance and self-regulation are impactful and effective. Scholarly evidence on the outcomes of CSR as a mode of governance (self-regulation by firm and/or industry, and multi-stakeholder governance) present a mixed picture. The literature highlights opportunistic firm behavior (Christmann 2004; Christmann and Taylor 2006; King and Lenox 2000; King et al. 2005), some benefits (Jayasinghe 2016), but also limitations of private regulations (Locke 2013; Malhotra et al. 2019; Sethi and Rovenpor 2016; Vogel 2010). Research also examines the possibility for corporate capture of MSIs (Bartley 2018; Hussain and Moriarty 2018; Khan and Lund-Thomsen 2011) and the hollowing out of the role of government (Burgoon and Fransen 2018). Much of this work casts doubts on the legitimacy and credibility of CSR as self- and private regulation and need further research. Given only limited exchange and collaboration among academic disciplines and sub-disciplines, and the multidisciplinary nature and the use of CSR as forms of regulation and governance (Wouters et al. 2013), forging cross- and multidisciplinary research collaborations can advance the conceptual and theoretical understanding of business ethics and CSR, and contribute to effective conduct, regulation, and governance of corporate and organizational behavior.

Graz et al. (2019) and Jackson et al. (2019) offer useful starting points in understanding how outcomes are linked to institutionally embedded actors and their interactions. Research and theorization on outcomes may require moving beyond CSR as a mode of governance and/or regulation and gaining expertise and inspiration from other fields such as international relations, law, political science, and sociology (Ciepley 2013; Kourula et al. 2019). Insights from other fields are likely to be useful in understanding both the complexity of interactions and considering the local marginalized voices. Cross-sector partnerships and their limitations remain an important topic, though still in need of better links to regulation and governance. Ultimately, we need to continue to problematize how each new paradigm perceives 
institutions and associated politics, actors, processes, their interactions, and the outcomes of these interactions.

\section{Conclusion}

With an interest in furthering scholarship on emerging paradigms of CSR, regulation, and governance, this thematic symposium includes papers that provide perspectives on CSR as an institutionally embedded phenomenon and as a mode of governance. These papers highlight and theorize the interface and role of corporations, governments, and nonstate actors in this institutional arena. The thematic symposium also opens new directions and frontiers for future research including problematizing existing frameworks, understanding institutionally embedded actors and complex processes, and questioning the politics and outcomes of these processes at different levels of analysis.

Acknowledgements The guest editors wish to thank Rudolf Sinkovics and Stephen Brammer for early contributions to this Thematic Symposium.

\section{References}

Alamgir, F., \& Banerjee, S. B. (2018). Contested compliance regimes in global production networks: Insights from the Bangladesh garment industry. Human Relations, 72, 272-297.

Alexander, R. (2019). Emerging roles of lead buyer governance for sustainability across global production networks. Journal of Business Ethics, 1, 11. https://doi.org/10.1007/s10551-019-04199-4

Arora, B. (2017). Multi-stakeholder initiatives: Journey and the future. Annual Review of Social Partnerships, 2017(12), 134-135.

Arora, B., Budhwar, P., \& Jyoti, D. (2019). Business responsibility and sustainability in India: Sectoral analysis of voluntary governance initiatives. London: Palgrave Macmillan.

Banerjee, S. B. (2008). Corporate social responsibility: The good, the bad and the ugly. Critical Sociology, 34(1), 51-79.

Banerjee, S. B. (2018). Transnational power and translocal governance: The politics of corporate responsibility. Human Relations, 71(6), 796-821.

Bartley, T. (2018). Rules without rights: Land, labor, and private authority in the global economy. Oxford: Oxford University Press.

Brammer, S., Jackson, G., \& Matten, D. (2012). Corporate social responsibility and institutional theory: New perspectives on private governance. Socio-Economic Review, 10(1), 3-28. https:// doi.org/10.1093/ser/mwr030.

Burgoon, B., \& Fransen, L. (2018). Might corporate social responsibility hollow out support for public assistance in Europe? British Journal of Industrial Relations, 56(1), 128-163.

Campbell, J. L. (2007). Why would corporations behave in socially responsible ways? An institutional theory of corporate social responsibility. Academy of Management Review, 32(3), 946-967. https://doi.org/10.5465/amr.2007.25275684.

Christmann, P. (2004). Multinational companies and the natural environment: Determinants of global environmental policy. Academy of Management Journal, 47(5), 747-760.

Christmann, P., \& Taylor, G. (2006). Firm self-regulation through international certifiable standards: Determinants of symbolic versus substantive implementation. Journal of International Business Studies, 37(6), 863-878.

Ciepley, D. (2013). Beyond public and private: Toward a political theory of the corporation. American Political Science Review, 107(1), 139-158.

Djelic, M. L., \& Etchanchu, H. (2015). Contextualizing corporate political responsibilities: Neoliberal CSR in historical perspective. Journal of Business Ethics, 142, 641-661.

Draude, A. (2017). The agency of the governed in transfer and diffusion studies. Third World Thematics: A TWQ Journal, 2(5), 577-587.

Ferraro, F., Etzion, D., \& Gehman, J. (2015). Tackling grand challenges pragmatically: Robust action revisited. Organization Studies, 36(3), 363-390.

Ford, M., \& Gillan, M. (2017). In search of a living wage in Southeast Asia. Employee Relations, 39(6), 903-914.

Fransen, L., \& Kolk, A. (2007). Global rule-setting for business: a critical analysis of multi-stakeholder standards. Organization, 14(5), 667-684. https://doi.org/10.1177/1350508407080305.

George, G. (2016). Management research in AMJ: Celebrating impact while striving for more. Academy of Management Journal, 59(6), 1869-1877.

Gilbert, D. U., \& Rasche, A. (2007). Discourse ethics and social accountability: The ethics of SA 8000. Business Ethics Quarterly, 17(02), 187-216.

Goodman, J., \& Arenas, D. (2015). Engaging ethically: A discourse ethics perspective on social shareholder engagement. Business Ethics Quarterly, 25(2), 163-189.

Graz, J.-C., Helmerich, N., \& Prébandier, C. (2019). Hybrid production regimes and labor agency in transnational private governance. Journal of Business Ethics. https://doi.org/10.1007/s1055 1-019-04172-1.

Hussain, W., \& Moriarty, J. (2018). Accountable to whom? Rethinking the role of corporations in political CSR. Journal of Business Ethics, 149(3), 519-534.

Jackson, G., Bartosch, J., Avetisyan, E., Kinderman, E., Knudsen, J. S. (2019). Mandatory non-financial disclosure and its influence on CSR: An international comparison. Journal of Business Ethics. https://doi.org/10.1007/s10551-019-04200-0

Jayasinghe, M. (2016). The operational and signaling benefits of voluntary labor code adoption: Reconceptualizing the scope of human resource management in emerging economies. Academy of Management Journal, 59(2), 658-677.

Khan, F. R., \& Lund-Thomsen, P. (2011). CSR as imperialism: Towards a phenomenological approach to CSR in the developing world. Journal of Change Management, 11(1), 73-90.

King, A. A., \& Lenox, M. J. (2000). Industry self-regulation without sanctions: The chemical industry's responsible care program. Academy of Management Journal, 43(4), 698-716.

King, A. A., Lenox, M. J., \& Terlaak, A. (2005). The strategic use of decentralized institutions: Exploring certification with the ISO 14001 management standard. Academy of Management Journal, 48(6), 1091-1106.

Kourula, A., Moon, J., Salles-Djelic, M. L., \& Wickert, C. (2019). Government and the governance of business conduct: Implications for management and organization. Organization Studies.

Kourula, A., Paukku, M., Peterman, A., \& Koria, M. (2018). Intermediary roles in regulatory programs: Toward a role-based framework. Regulation \& Governance. $\mathrm{https} / / /$ doi.org/10.1111/rego.12226.

Lee, S. H., Mellahi, K., Mol, M. J., \& Pereira, V. (2019). No-sizefits-all: Collaborative Governance as an alternative for addressing labour in global supply chains. Journal of Business Ethics. https ://doi.org/10.1007/s10551-019-04198-5

Levy, D. (2008). Political contestation in global production networks. Academy of Management Review, 33(4), 943-963. https://doi. org/10.5465/AMR.2008.34422006. 
Locke, R. M. (2013). The promise and limits of private power: Promoting labor standards in a global economy. Cambridge: Cambridge University Press.

Malhotra, N., Monin, B., \& Tomz, M. (2019). Does private regulation preempt public regulation? American political Science Review, 113, 19-37.

Manning, S., Boons, F., Von Hagen, O., \& Reinecke, J. (2012). National contexts matter: The co-evolution of sustainability standards in global value chains. Ecological Economics, 83, 197-209. https://doi.org/10.1016/j.ecolecon.2011.08.029.

Margolis, J. D., \& Walsh, J. P. (2003). Misery loves companies: Rethinking social initiatives by business. Administrative Science Quarterly, 48(2), 268-305. https://doi.org/10.2307/3556659.

Matten, D., \& Crane, A. (2005). Corporate citizenship: Toward an extended theoretical conceptualization. Academy of Management Review, 30(1), 166-179.

Matten, D., \& Moon, J. (2008). "Implicit" and "explicit" CSR: A conceptual framework for a comparative understanding of corporate social responsibility. Academy of Management Review, 33(2), 404-424.

Ozkazanc-Pan, B. (2018). CSR as gendered neocoloniality in the Global South. Journal of Business Ethics. https://doi.org/10.1007/ s10551-018-3798-1.

Pisani, N., Kourula, A., Kolk, A., \& Meijer, R. (2017). How global is international CSR research? Insights and recommendations from a systematic review. Journal of World Business, 52(5), 591-614.

Scherer, A. G., \& Palazzo, G. (2007). Toward a political conception of corporate responsibility: Business and society seen from a Habermasian perspective. Academy of Management Review, 32(4), 1096-1120.

Sethi, S. P., \& Rovenpor, J. L. (2016). The role of NGOs in ameliorating sweatshop-like conditions in the global supply chain: The Case of Fair Labor Association (FLA), and Social Accountability International (SAI). Business and Society Review, 121(1), 5-36.

Sethi, S. P., \& Schepers, D. H. (2014). United Nations global compact: The promise-performance gap. Journal of Business Ethics, 122(2), 193-208.
Sheehy, B. (2015). Defining CSR: Problems and solutions. Journal of Business Ethics, 131(3), 625-648.

Utting, P. (2014). Multistakeholder regulation of business: Assessing the pros and cons. In R. Van Tulder, A. Verbeke, \& R. Strange (Eds.), International business and sustainable development (pp. 425-446). Bingley: Emerald Group Publishing Limited.

Utting, P., \& Marques, J. (2009). Corporate social responsibility and regulatory governance: Towards inclusive development?. New York: Springer.

Vogel, D. (2010). The private regulation of global corporate conduct: Achievements and limitations. Business \& Society, 49(1), 68-87.

Waddock, S. (2008). Building a new institutional infrastructure for corporate responsibility. The Academy of Management Perspectives, 22(3), 87-108.

Whelan, G. (2012). The political perspective of corporate social responsibility: A critical research agenda. Business Ethics Quarterly, 22(4), 709-737.

Wijen, F. (2014). Means versus ends in opaque institutional fields: Trading off compliance and achievement in sustainability standard adoption. Academy of Management Review, 39(3), 302-323.

Wilks, S. (2013). The political power of the business corporation. Cheltenham: Edward Elgar.

Wouters, J., Bijlmakers, S., Hachez, N., Lievens, M., \& Marx, A. (2013). Global governance and democratic legitimacy: A bottom-up approach. Innovation: The European Journal of Social Science Research, 26(3), 197-200. https://doi.org/10.1080/13511 610.2013.771898

Publisher's Note Springer Nature remains neutral with regard to jurisdictional claims in published maps and institutional affiliations. 